\title{
Music of the 1960s: The Praxis of Ideological Change
}

\author{
Philip Poe \\ Mississippi State University \\ Melody Fisher \\ Mississippi State University \\ Stephen Brandon \\ Mississippi State University \\ Darvelle Hutchins \\ University of Missouri \\ Mark Goodman \\ Mississippi State University
}

In this article, we consider music as the praxis of ideology in the 1960s within the framework of Burke's rhetoric of transformation. The 1960s were a period of cultural change in the United States and around the world-the civil rights movement, protests against the Vietnam War, challenges to communism in Eastern Europe, liberation politics around the world. The role of music as a unifying element among those people advocating change is well established in scholarship. We take that consideration of the role of music into a discussion of how music became the praxis of ideology, providing a place where millions of people could advocate for change and be part of the change by interacting with the music.

Keywords: rhetoric of transformation, praxis, Kenneth Burke, 1960s, music as ideology

\section{Introduction}

The early and middle 1960s witnessed an unprecedented collective movement that would reach its rhetorical climax in 1968 as young people challenged the status quo of their parents' generation. The counterculture evolved with the rising tensions of generational malcontent that exposed political dysfunction, intense racism, social inequality, and the Vietnam War. The rhetorical engines of persuasive music powered the social movement of the 1960s-protest music, Beatlemania, the British Invasion, and flower-power-fueled the fires of conflictional discourse and created an explosive backdraft of social reformation. As a result, music became the praxis of an ideological emancipation that challenged oppression and demanded equality as a universal right. A consideration of specific pieces of music in this article demonstrates how the music became the praxis of a new ideological order. In fact, Tierney and Sallee (2008) contended that the explicit goal of praxis is to "empower marginalized peoples and help them challenge their oppression" (p. 676). In the early to mid-60s, music became the lighting rod that transformed and "self-actualized" young people into the practice of reflection and action. 


\section{Praxis as Ideological Action}

In its simplest form, praxis is essentially theory in action-here, however, praxis abandons theory in favor of an ideology conceived in action. Through this action, the embryonic "self" of a young generation became a collective identity umbilically connected through music. In consequence, a rhetorical vision was born that would propagate - through action, peace, justice, and equality. The newborn praxis-based ideology would manifest itself in the music of the 1960s-it would feed and grow exponentially, and the music would become the catalyst for a deliberate and radical social change. The praxis of the counterculture would initiate an unstable balance among the worldviews of young and old, Black and White, conservative and liberal, and oppressor and oppressed. Caught in the middle of the conflict were governments seeking to carry out the ideology of the generation who fought the World War while its children sought governmental change to operationalize the idealism inherent in that ideology.

\section{Rhetoric of Transformation}

Kenneth Burke (1966) explained that the use of symbols is inherently ideological; accordingly, the process of selecting the symbols is the praxis of the ideology. Symbolism is ideological, explained Burke, because symbols state a preference for an ideology by what is conveyed, but also by what is not stated. That which is not stated leaves silent the ideology inherent in the not-used, not-preferred symbols of the user. In effect, silent and articulated symbols are both praxis of the ideology.

Ideology precedes praxis. "An 'ideology' is like a god coming down to earth, where it will inhabit a place pervaded by its presence," wrote Burke (1966, p. 6). The ideology of World War II dominated the world in the aftermath of the war, which was fought on battlefields on every continent. Burke notes that the praxis of the postwar ideology went two directions. The oppositional directions came from a similar motivation, what Burke (1969) described as "a search for father" (p. 11). Some children of the World War II generation (usually identified as Baby Boomers) sought to honor the experience of their parents by going into the military, like the members of their family who fought in the war. Other children sought to achieve the ideals of the war effort. Former President Franklin D. Roosevelt set out the goals of the war effort in a speech delivered January 6, 1941 (before the United States entered the war that December). Roosevelt (1941) identified the four freedoms everyone in the world had a right to: freedom of speech and expression, freedom of every person to worship god in his own way, freedom from want, and freedom from fear.

The fulfillment of a world built on the ideology articulated by Roosevelt became even more poignant to the Baby Boomers when John Kennedy delivered his inaugural address on January 20, 1961, challenging Americans to make the world safe for democracy and freedom: "And so, my fellow Americans: ask not what your country can do for you-ask what you can do for your country" (Kennedy, 1961, line 26). This search for Baby Boomer identity in a world dominated by the parents who fought and survived the World War contributed to the ideological confrontations of the 1960s. Burke (1969) identified this ideological conflict as the rhetoric of transformation. As Burke explained, "The range of images that can be used for concretizing the process of transformation is limited only by the imagination and ingenuity of poets" (p. 232).

\section{Music as Praxis in the 1960s}

As Brandon, Maupin, and Goodman (2017) have argued, the poets of change in the 1960s "became a unifying force into the wide and varied reality of the protest movements of the 1960s" (p. 369). By listening to the music, the Baby Boomers—regardless of nationality or issue — could join the 
movement for a new world ideology because they were identifying with the poets calling for change. As Burke (1969) explained, "The individual person, striving to form himself in accordance with the communicative norms that match the cooperative ways of his society, is by the same token concerned with the rhetoric of identification" (p. 39).

In the middle and late 1960s, that "rhetoric of identification" manifested itself through music. In fact, as Chenoweth (1971) argued, music became a force for collective action and created a rhetorical shift in the perspectives of many young people. As a result, a transformative ideology was formed that challenged their parent's vision of American democracy - the performance of the music became the praxis by which the postwar generation created a collective identify in a postwar world.

"The Summer of Love" (i.e., June through August of 1967) brought the underground counterculture into the mainstream of American culture and society. The seeds of "flower power" germinated in an array of sound and color, while eastern mysticism and the quest for inner consciousness explored new ways of perceiving life. The collective movement known as "psychedelia" bloomed a praxis-based ideology conceived in action but dedicated to self-transformation. At the epicenter of this "selfactualized introspection" was psychedelic music, which allowed people "to leave the insanity of the real world and exists in a reality outside of culture" (Chenoweth, 1970, p. 30). This exit from reality was especially relevant to the events of that time such as the Vietnam War and nuclear proliferation. But psychedelia was much more than escapism from the war or postwar culture-psychedelic music created an identity of "being." Innerconscious exploration through music and drugs opened Timothy Leary's (1968) "doors of perception" to new ways of experiencing the world. Through praxis of this ideology, members of the psychedelic movement could rhetorically transform themselves and become mentally and physically emancipated from the chains of the postwar society of their parents.

Bromwell (2002) argued that music "establishes a feeling of space inside us, and when it opens this space, it enlarges us" (p. 73). This new space was obviously enhanced through the use of LSD and marijuana. Drugs, especially "hallucinogenic" ones such as LSD, were thought to "suppress the false and misleading modes of understanding imposed by school and society" and open the mind to a new world of "higher consciousness" of knowledge and modes of understanding (Covach \& Flory, 2015, p. 251). But, with or without drugs, psychedelic music was the vortex of the social and cultural revolution of the 1960s. Armed with music and eastern mysticism, American youths waged war on "normalcy." Psychedelic music became the praxis that allowed young people to question and critique cultural institutions such churches, universities, capitalism, and governments-it was through music that a new rhetoric of transformation developed. Or, as Burke (1969) succinctly stated, it was the "individual person" attempting to find his or her cultural identity within the rhetorical vision of the counterculture (p. 39).

Writing and performing psychedelic music was a praxis of the counterculture ideology. The first tremors of psychedelic music hit the charts in 1966 with The Byrds' "Eight Miles High," a song that connected drug use to a core element in rock music and youth culture (Unterberger, 2003). However, it was the Beatles album Revolver and John Lennon and Paul McCartney's (1966, side 2, track 7) seismic song "Tomorrow Never Knows" that ushered in the first psychedelic music and brought attention to the underground counterculture.

Turn off your mind, Relax and float down stream It is not dying, it is not dying. 
The song continues with the mantra of the upcoming psychedelia era of counterculture flower power and the quest for inner consciousness:

\author{
Yet you may see \\ The meaning of within \\ It is being, it is being \\ Love is all \\ And love is everyone, \\ It is knowing, it is knowing.
}

"Tomorrow Never Knows" sent rhetorical shockwaves through mainstream pop culture. The song was instrumental in changing a postwar world of "normalcy" into a radical praxis of "being" and ideological emancipation. The song was technologically unprecedented with dueling mellotrons, overlapping tape loops, and accelerated sitar saturation (McDonald, 1994 p. 95). Many critics (e.g., Bromwell, 2002) have argued that it is one of the most significant songs of the 1960s. Furthermore, Beatles scholar Mark Lewisohn (2000) labeled "Tomorrow Never Knows" as a "masterpiece" and a "quantum jump" into time (p. 93). McDonald (1994) claimed that the song "introduced LSD and Leary's psychedelic revolution to the young of the Western World" (p. 93). Nevertheless, "Tomorrow Never Knows" and Lennon's foray into psychedelic drugs set into action the aftershocks of counterculture praxis that would clash with the postwar generation of songs such "The Ballad of the Green Berets" (Sadler, 1966, single). In fact, love songs and patriotic songs would take back stage to the counterculture "within and without" of the new artistic and existential psychedelic musicunquestionably, a new rhetorical shift had taken place and the ideological landscape of the Western World would soon change dramatically.

Within a year of the release of Revolver and "Tomorrow Never Knows," psychedelic music would reach its height. Praxis is putting ideologies into action-writing and performing psychedelic music became the action of a collective generation in search of alternative approaches to "being" and life. The current praxis of American culture at the time called for "patriotic dialogue" and moral decency. At the 1967 Monterey International Pop Music Festival in Monterey, California, Jimi Hendrix put lighter fluid on his guitar and set it aflame at the end of his performance. The shock of a flaming guitar symbolized the torch that would light a new ideological rhetoric. His actions obviously conflicted with normal behavior which signaled a new praxis-one that countered the hegemony of a postwar ideology. Other rock bands and artists, such as Jefferson Airplane, The Doors, the Grateful Dead, Arlo Guthrie, Janis Joplin, Country Joe and the Fish, the Rolling Stones, and of course, The Beatles-just to name a few-soon took up the torch to light a new world of individual transformational praxis through psychedelic music.

The youths who once demanded an ideological emancipation for the oppressed now demanded freedom for themselves. The difference, however, came from "within" rather than "without"-in other words, the material world became meaningless while the inner world became meaningful. Jim Morrison of The Doors set in motion his praxis with the acid rock anthem "Light My Fire" (The Doors, 1966, single), which was released in the summer of 1967 at the beginning of the "flower power" summer. In 1981, Lizzi James discussed her famous interview with Morrison, which had occurred in 1968. In that interview, Morrison stated, "I offer images-I conjure memories of freedom that can still be reached-like the Doors, right? But we can only open the doors—we can't drag people through. I can't free them unless they want to be free-" (James, 1981, line 432). Morrison's concept of "freedom" fits with Burke's (1969) “concretizing process of transformation...that is limited only by the imagination and ingenuity of poets" (p. 12). This is further confirmed in the ideological 
praxis of Janis Joplin ("Me and Bobby McGee," Kristofferson \& Foster, 1969, side 2, track 2) as she sang,

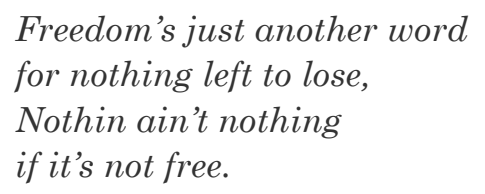

It was freedom-freedom to do one's thing-that offered the cultural alternatives that were so attractive to young people in the 1960s. Writing music, playing music, and listening to music permitted a means to escape the limitation of societal rules and put into praxis an ideology of personal freedom. Listening to the music of "the poets" was the praxis of cultural violation and inner freedom.

In the words of Jim Morrison in 1968 and recalled by James in 1981, "it's possible for there to be a transcendence-but not on a mass level, not a universal rebellion. Now it has to take place on an individual level - every man for himself, as they say. Save yourself" (lines 449-450). The "psychedelic god," as he was once labeled, first introduced his transformative rhetoric with the early1967 hit, "Break on Though (To the Other Side)" (The Doors, 1967, side A, track 1) another countercultural anthem that encouraged listeners to eschew an outdated social reality and "break on through to the other side" of consciousness through free-thinking and psychedelic drug use, literal manifestations of the ideological praxis Morrison and The Doors sang about.

Where psychedelic music spoke of inhibition, individuality, and a diversion from reality, rhythm and blues and soul music illustrated the civil unrest and discontentment of the time. A larger audience accepted rhythm and blues and soul music because those genres communicated frustration and anger while defining the purpose of the civil rights movement- "to end racism, promote peace and establish federal law stating that all individuals, no matter their race, deserve to be treated in a fair and just fashion" (Kent State University, n.d., line 7).

At the height of the movement, many musical artists used their lyrics as a form of protest. Two such artists, Sam Cooke and Nina Simone, used music as praxis to unabashedly protest discriminatory treatment of African Americans. Sam Cooke refused to play for segregated audiences, and after being denied accommodations at a hotel, he wrote what is known as the anthem of the civil rights movement, "A Change Is Gonna Come" (Cooke, 1964, side 2, track 7; Guralnick, 2005; National Public Radio, 2014):

I go to the movie and I go downtown Somebody keep tellin' me don't hang around

It's been a long, a long time coming

But I know a change gonna come, oh yes it will

Then I go to my brother

And I say brother help me please

But he winds up knockin' me

Back down on my knees, oh

There have been times that I thought I couldn't last for long

But now I think I'm able to carry on 


\title{
It's been a long, a long time coming \\ But I know a change is gonna come, oh yes it will.
}

Addressing social ills directly, the song was a departure from the messages of Cooke's past crossover hits. It also was also risky for Black artists: "the last thing Sam Cooke wanted to do was to alienate his new audience. But he also came from the gospel world. He could not ignore moral outrage right in front of him" (National Public Radio, 2014).

Black artists singing of their own oppression was troubling and yet liberating. Their vast audience base looked at them as individuals who had risen above or even escaped the atrocities of their peer intergroup, while in reality, they used music as praxis to communicate their own grievances and conflicted emotions. As a child, Nina Simone witnessed discrimination against her parents (Loudermilk, 2013). That experience served as the impetus for her vociferous lyrical protest against systemic racism. She created several songs that describe her angst of the time. Instead of the optimism found in Cooke's lyrics, Simone voiced rage and frustration. She wrote "Mississippi Goddam" (Simone, 1964, track 7) after the 1963 assassination of National Association for the Advancement of Colored People field secretary Medgar Evers:

Oh but this whole country is full of lies

You're all gonna die and die like flies

I don't trust you any more

You keep on saying "Go slow!"

"Go slow!"

\author{
But that's just the trouble \\ "Do it slow" \\ Desegregation \\ "Do it slow" \\ Mass participation \\ "Do it slow" \\ Reunification \\ "Do it slow" \\ Do things gradually \\ "Do it slow" \\ But bring more tragedy \\ "Do it slow" \\ Why don't you see it \\ Why don't you feel it \\ I don't know \\ I don't know.
}

Simone's explicit, in-your-face style was not appreciated by all, as it was "boycotted in certain southern states. Specifically, promotional copies were smashed by a Carolina radio station and returned to Simone's record label” (Abdul, 2016, para 7).

\section{Conclusion}

Our survey of the music of the 1960s is incomplete. Ideology was put into praxis in hundreds of coffee shops, through thousands of guitar players picking tunes in parks and living rooms, in concerts on every college campus, and at demonstrations around the world. Any person sitting at home alone 
listening to Sergeant Pepper's Lonely Hearts Club Band (Lennon \& McCartney, 1967) or in a car with friends listening to the Top 40 was a participant.

Music is a unique medium for the praxis of ideology. Former President Kennedy's speech moved people and may have inspired them toward a better world, but they did not gather to recite the words. Catcher in the Rye (Salinger, 1951) may have been the novel of change for those coming of age in 1960. The Graduate (Turman \& Nichols, 1967) or Easy Rider (Fonda \& Hopper, 1969) or Vanishing Point (Spencer, Pearson, Cowdray, \& Sarafian, 1971) brought the praxis of the ideology of change into the movie theaters. But, music is where the poets and musicians lived, and it is where Burke's culture of transformation was being voiced over and over, hour after hour around the world. Music was a living, breathing element of change that came to life just by humming the lyrics or playing the 45 on the record player. Other media events may have been moments, but music was a state of being - the unifying element, in fact-that helped change the ideology of American society among people participating in Burke's culture of transformation.

\section{References}

Abdul, R. (2016, July 2). Nina Simone: Singer, songwriter, civil rights campaigner. Retrieved from https://www.blackhistorymonth.org.uk/article/section/bhm-heroes/nina-simone-singersongwriter-civil-rights-campaigner/

Brandon, S., Maupin, I., \& Goodman, M. (2017). Bob Dylan: The prophet of social change in the 1960s. Media Watch, 8, 366-377.

Bromwell, N. K. (2002). Tomorrow never knows: Rock and psychedelics in the 1960s. Chicago, IL: University of Chicago Press.

Burke, K. (1966). Language as symbolic action: Essays on life, literature, and method. Berkeley, CA: University of California Press.

Burke, K. (1969). A rhetoric of motives. In C. Kallendorf (Ed.), landmark essays on rhetoric and literature (Volume 16; pp. 225-242). Los Angeles, CA: University of California Press.

Chenoweth, L. (1971). The rhetoric of hope and despair: A study of the Jimi Hendrix experience and the Jefferson Airplane. American Quarterly, 23, 25-45.

Cooke, S. (1964). A change is gonna come. On Ain't That Good News [Vinyl]. Hollywood, CA: RCA.

Covach, J., \& Flory, A. (2015). What's that sound? An introduction to rock and its history (4th ed.). New York, NY: W. W. Norton.

Fonda, P. (Producer), \& Hopper, D. (Director). (1969). Easy rider [Motion picture]. United States: Columbia Pictures.

Guralnick, P. (2005, September 22). The man who invented soul. Rolling Stone. Retrieved from https://web.archive.org/web/20090206220302/http://www.rollingstone.com/news/story/766121 1/the_man_who_invented_soul

James, L. (1981). Jim Morrison: Ten years gone. Creem Magazine. Retrieved from http://archives.waiting-forthe-sun.net/Pages/Interviews/JimInterviews/TenYearsGone.html

Kennedy, J. F. (1961, January 20). Inaugural address [Speech]. Retrieved from http://voicesofdemocracy.umd.edu/kennedy-inaugural-address-speech-text/

Kent State University. (n.d.). Role of music in the civil rights movement. Retrieved from https://musicedmasters.kent.edu/the-role-of-music-in-the-civil-rights-movement/

Kristofferson, K.., \& Foster, F. (1969). Me and Bobby McGee. On Pearl. New York, NY: Columbia. 
Leary, T. (1968). High priest. New York, NY: New American Library.

Lennon, J., \& McCartney, P. (1966). Tomorrow never knows. On Revolver [Vinyl]. London, United Kingdom: Parlophone.

Lennon, J., \& McCartney, P. (1967). Sergeant Pepper's lonely hearts club band [Vinyl]. London, United Kingdom: Parlophone.

Lewisohn, M. (2000). I was alone, I took a ride. Revolver, Revolution, Technology. In N.K. Bromwell (Ed.), Tomorrow never knows: Rock and psychedelics in the 1960s (pp. 83-102). Chicago, IL: University of Chicago Press.

Loudermilk, A. (2013). Nina Simone and the civil rights movement: Protest at her piano; audience at her feet. Journal of International Women's Studies, 14, 121-136.

MacDonald, I. (1994). Revolution in the head: The Beatles' records and the sixties. Chicago, IL: Chicago Review Press.

National Public Radio. (2014, February 1). Sam Cooke and the song that almost scared him. Retrieved from https://www.npr.org/2014/02/01/268995033/sam-cooke-and-the-song-thatalmost-scared-him

Roosevelt, F. D. (1941). The "four freedoms" [Speech]. Retrieved from http://www.speechesusa.com/Transcripts/franklin_roosevelt-four.html

Sadler, B. (1966). The Ballad of the Green Berets. Single [Vinyl]. New York, NY: RCA Victor.

Salinger, J.D. (1951). The catcher in the rye. New York, NY: Little, Brown, and Company.

Simone, N. (1964). Mississippi goddam. On Nina Simone in Concert [Vinyl]. Amsterdam, The Netherlands: Phillips.

Spencer, N., Pearson, M., \& Cowdray, V. (Producers), \& Sarafian, R.C. (Director). (1971). Vanishing point [Motion picture]. United States: 20th Century Fox.

The Doors. (1966). Light my fire. Single [Vinyl]. Hollywood, CA: Elektra.

The Doors. (1967). Break on through (to the other side). On The Doors [Vinyl]. Hollywood: RCA Victor.

Tierney, W. G., \& Sallee, M. W. (2008). Praxis. In L. M. Given (Ed.), The SAGE encyclopedia of qualitative research methods (pp. 675-676). Thousand Oaks, CA: SAGE.

Turman, L. (Producer), \& Nichols, M. (Director). (1967). The graduate [Motion picture]. United States: Embassy Pictures and United Artists.

Unterberger, R. (2003). Eight miles high: Folk-rock's flight from Haight-Ashbury to Woodstock. London, United Kingdom: Backbeat Books.

The Journal of Social Change, sponsored by Walden University, welcomes manuscripts focusing on interdisciplinary research in social change that improves the human condition and moves people, groups, organizations, cultures, and society toward a more positive future.

Walden University Publishing: http://www.publishing.waldenu.edu 